\title{
Developing Writing Blended Approach to Increase Students’ Descriptive Writing Competency
}

\author{
Jaja Hidayat \\ Department of English, Teacher Training and Education Faculty, \\ University of Lampung Lampung Province, Indonesia
}

\begin{abstract}
This quantitative research was to find out whether there was a statistically significant difference of students' descriptive writing competency taught through Blended approach and the traditional one and to find out the effectiveness of the Blended approach in increasing students' descriptive writing competency. The subjects were 29 students of the second grade of SMP 1 Purbolinggo, east Lampung. The instruments used were descriptive writing tests. The data were analysed by using Repeated Measure t-test. The result showed that there was a statically significant difference of students' descriptive writing competency taught through Writing Blended approach and the traditional one with the significant level 0.05. This suggests that Blended Approach to Writing promotes the students to increase students' descriptive writing competency.
\end{abstract}

Keywords: Blended Approach to writing, Effectiveness, Writing competency

\section{INTRODUCTION}

Writing is a mental activity or process resulting from the interactions of multiple cognitive sub processes that a writer implements to generate, express, and refine one's ideas while formulating a text (Berninger, 1994; Flower \& Hayes, 1981; Hayes, 2012). As one of the fundamental skills of English (Javed, Juan and Nazli, 2013; Al-Mansour and Al-Shorman, 2014; Huy, 2015; Keskin, 2015), writing belongs to a person's productive ability. It is the physical act of committing words or ideas to some medium, whether it is hieroglyphics inked onto parchment or an e-mail message typed into a computer. On the other hand, writing is the mental work of inventing ideas, thinking about how to express them, and organizing them into statements and paragraphs that will be clear to a reader (Nunan, 2003: 98).

Furthermore, Lieberman and Wood (2003: 19) say that writing produces occasions to foreground and clarify thinking; to record, shape, and analyse experiences; to express internal lives; to explore ideas learned from others. Rochberg (2004: 2) says that writing therefore related the constellations to cuneiform signs from which one could read and derive meaning, and thus expressed the idea that written messages were encoded in celestial phenomena. Nadler et. al. (2005: 128) state that writing is the uses of appropriate letters and symbols according to the standard usage of a given language. It means that writing skill studies about how to understand the graphic system such as letter, words, and sentences. A group of letters become word and has a meaning.

Several researchers have demonstrated personal success in disciplines strongly related to a person's writing ability (Lerstrom, 1990) and depends on good writing skills (Cho \& Schunn, 2007). Specifically, good writing skills are required training since prior research has proven that writing is an important part of the elementary school curriculum (Lidvall, 2008). However, most students are usually apprehensive toward writing activities, and writing instruction remains an area of low 
interest for those students (Lidvall, 2008; Clark, 2004). Moreover, the majority of the students are more prone to memorizing and imitation; they fail to integrate critical thinking into their creative writings (Hasan \& Akhand, 2010). Therefore, a better understanding of how to develop a suitable learning strategy or authoring tool to enhance students' writing interest is necessary.

Process approach, as a method, had a significant impact to the improvement of students' writing skill (Nabhan, 2016). In addition, the process approach to teaching writing can be and is ideally applied in different teaching models (Sun \& Feng, 2009). Process approach can be one of the alternative ways in teaching essay writing (Rotua, 2010). On the other hands, ESL students at the Maryland Correctional Institution in Jessup have found success as beginning writers by using a product approach to writing (Gardner, 2016). Although the product approach is no longer used in mainstream education classes, it allows low-literacy students to achieve success early in their literacy education. This success is important in a nontraditional environment where students are passive learners, having low self-confidence in the academic environment, and struggle for perfection (Gardner, 2016).

Many studies have been conducted on product and process approach to increase students' writing competency. For instance, (Hasan \& Akhand, 2010) states that the conflict of product and process approach begins with the level of the students. In most of the English as a Second Language (ESL)/English as a Foreign Language (EFL) classes, (Hasan \& Akhand, 2010) have mixed ability group that vary so widely that only one approach cannot be adopted. While in some classes product approach may prove fruitful, process approach may be useful for another. Some scholars also opt for genre approach. This scientific paper argues that the bridging of the two might be a rightful claim to enhance the writing courses. Most scholars see these two concepts as complementary rather than opposites.

In this scientific paper, the strengths and weaknesses of product and process approach in terms of writing and how the blend of product and process approach in ESL/EFL Classes showcases the development of writing are analysed. Therefore, (Hasan \& Akhand, 2010) prove that the two approaches- product and process are complementary; both approaches help the other one to make a complete whole. As a result, developing writing blended approach to increase students' descriptive writing competency needs to be calculated as follows:

1. Is there any significant difference of students' descriptive writing competency taught through Writing Blended approach and the traditional one?

2. How effective is the Writing Blended approach in increasing students' descriptive writing competency?

Another calculation needs to be conducted is hypothesising the expectations. Hypothesis is a temporary conclusion about the research. Furthermore, Hypothesis is also known as a speculation concerning either observed or expected relationships among phenomena. If for research purposes the speculation is translated into a statement that can be tested by quantitative methods in research, the statement is known as a statistical hypothesis, stated with reference to population parameters (e.g. population mean) and takes the form of two opposing but related hypotheses: a null hypothesis, symbolized by $\mathrm{H} 0$, and an alternative hypothesis, symbolized by $\mathrm{Ha}$ or $\mathrm{H} 1$, that are mutually exclusive and exhaustive. A null hypothesis is a statement that "No difference exists between groups A and B" whereas the alternative hypothesis is an opposite statement that "The mean for group A is higher than that for group B" (Richards and Schmidt, 2010: 266-267). The hypotheses of this research are explained as follows: 
H0: There is no significant difference in students' writing achievement before and after the implementation of blended writing in peer review.

HI: There is significant difference in students' writing achievement before and after the implementation of blended writing in peer review.

\section{LITERATURE REVIEW}

In relation to this study, there are several points of theories and previous studies which should be reviewed. Moreover, some concepts are also described in order to give similar understanding. Thus, this chapter discusses about writing, writing competency, teaching writing, effective writing, a product approach, a process approach, blended approach.

\section{Writing}

Writing is the physical act of committing words or ideas to some medium, whether it is hieroglyphics inked onto parchment or an e-mail message typed into a computer. On the other hand, writing is the mental work of inventing ideas, thinking about how to express them, and organizing them into statements and paragraphs that will be clear to a reader (Nunan, 2003: 98). Furthermore, Lieberman and Wood (2003: 19) say that writing produces occasions to foreground and clarify thinking; to record, shape, and analyse experiences; to express internal lives; to explore ideas learned from others. Rochberg (2004: 2) says that writing therefore related the constellations to cuneiform signs from which one could read and derive meaning, and thus expressed the idea that written messages were encoded in celestial phenomena.

\section{Writing competency}

On a written assignment, the student will demonstrate the ability to 1 ) generate relevant and sufficient content; 2) organize his or her thoughts coherently; 3) use correct terminology and rich vocabulary in the fulfilment; and 4) use effective complex constructions; 5), adhere to the conventions of correct mechanics and sentence structure, at the school level, of his or her writing assignments.

It is in line with Heaton (1991: 135) who states that there are five aspects evaluated in writing; they are content, organization, vocabulary, Language use and mechanic.

\section{Teaching of writing}

Teaching writing would be an easy task Fahim and Rahimi (2011 in Jafarin and Zarei, 2015:100). Expressing ideas or simply communicating for that matter, in writing, can be slow and difficult, especially for learners. Teaching writing is to teach the students how to express the idea or imagination in written form. In order to be successful in writing, the material presented should be relevant to their needs, interest, capacities, and ages until they are able to make composition with view or even no errors, Finnochiaro, (1964). In other words, it is clear that in teaching writing the teacher should know what the students' interest, the students' capability, and the students' age. The factors are important to know because the teacher can give the suitable way to teach. When the teacher knows about the students' interest, giving the material connected with their interest. It is good for the students because they can express their feeling in a group of words, sentences and paragraph.

\section{Product Approach}

A product approach, a traditional approach in which students are encouraged to mimic a model text, usually is presented and analysed at an early stage" (Gabrielatos, 2002, p.5). For example, in a typical product approach-oriented classroom, students are supplied with a standard sample of text and they are expected to follow the standard to construct a new piece of writing.

Product Approach Model comprises of four stages (Steele, 2004)

Stage one: Students study model texts and then the features of the genre are highlighted. For example, if studying a formal letter, students' attention may be 
drawn to the importance of paragraphing and the language used to make formal requests. If a student reads a story, the focus may be on the techniques used to make the story interesting, and students focus on where and how the writer employs these techniques.

Stage two: This stage consists of controlled practice of the highlighted features, usually in isolation. So if students are studying a formal letter, they may be asked to practise the language used to make formal requests, for example, practising the 'I would be grateful if you would...' structure.

Stage three: This is the most important stage where the ideas are organized. Those who favour this approach believe that the organization of ideas is more important than the ideas themselves and as important as the control of language.

Stage four: This is the end product of the learning process. Students choose from the choice of comparable writing tasks. To show what they can be as fluent and competent users of the language, students individually use the skills, structures and vocabulary they have been taught to produce the product.

\section{Process Approach}

Kroll (2001), as cited in Hasan \& Akhand (2010), defines process approach as follows:

The "process approach" serves today as an umbrella term for many types of writing courses .... What the term captures is the fact that student writers engage in their writing tasks through a cyclical approach rather than a single-shot approach. They are not expected to produce and submit complete and polished responses to their writing assignments without going through stages of drafting and receiving feedback on their drafts, be it from peers and/or from the teacher, followed by revision of their evolving texts. (pp. 220221).

Hence a process approach tends to focus more on varied classroom activities which promote the development of language use: brainstorming, group discussion and rewriting.

\section{Blended learning approach}

Blended learning approach/ a collaborative approach is the collaboration of Product approach and Process approach in writing. In this research, Product approach and Process approach will be blended/collaborated to increase students' descriptive writing competency.

\section{MATERIALS \& METHODS}

This is a quantitative research with one group pre-test and post-test design. The research population is the students of the second grade of SMPN 1 Purbolinggo east Lampung and the sample of the research is class VIII consisting of 29 students: 25 females and 4 males. The activities were started from administering pre-test, doing treatment, and administering post-test.

The instruments used were descriptive writing tests. The descriptive writing test was administered twice: in pretest and post-test. Pre-test was conducted to know the students' descriptive writing competency before the treatment and posttest was given to know the students' descriptive writing competency after the treatment. The descriptive writing test was describing an animal, elephant. In analysing the data, repeated measure t-test was used to prove the hypothesis and to know if the research was significant by looking at the results of pre-test and post-test.

\section{RESULT}

From the Statistics and the Gender below, it is found that all of the participant did both the pre-test and post-test. So, there is no missing data at the three variables. Most of the students are female with the percentage $86.2 \%$ and the rest are male, $13.8 \%$.

\begin{tabular}{|l}
\multicolumn{7}{c|}{ Table 1: Statistics } \\
\begin{tabular}{|c|c|c|c|c|}
\hline \multicolumn{7}{|c|}{ STATISTICS } \\
\hline \multicolumn{2}{|c|}{} & Gender & Pre-Test & Post-Test \\
\hline \multirow{2}{*}{ N } & Valid & 29 & 29 & 29 \\
\cline { 2 - 5 } & Missing & 0 & 0 & 0 \\
\hline
\end{tabular}
\end{tabular}

Table 3 below shows the students score of Pre-test. The Pre-test itself is 
actually the test for Traditional writing approach. In this table, it is seen that the lowest score was 53 and the highest score was 68. The most frequent score coming up is 62 owned by six students. It means that $20.7 \%$ of the students have such score.

\begin{tabular}{|c|c|c|c|c|c|}
\hline \multicolumn{6}{|c|}{ GENDER } \\
\hline & & Frequency & Percent & Valid Percent & Cumulative Percent \\
\hline \multirow[t]{3}{*}{ Valid } & Female & 25 & 86.2 & 86.2 & 86.2 \\
\hline & Male & 4 & 13.8 & 13.8 & 100.0 \\
\hline & Total & 29 & 100.0 & 100.0 & \\
\hline
\end{tabular}

\begin{tabular}{|c|c|c|c|c|c|}
\hline \multicolumn{6}{|c|}{ Pre-Test } \\
\hline & & Frequency & Percent & Valid Percent & Cumulative Percent \\
\hline \multirow{13}{*}{ Valid } & 53 & 1 & 3.4 & 3.4 & 3.4 \\
\hline & 54 & 1 & 3.4 & 3.4 & 6.9 \\
\hline & 56 & 1 & 3.4 & 3.4 & 10.3 \\
\hline & 58 & 2 & 6.9 & 6.9 & 17.2 \\
\hline & 60 & 3 & 10.3 & 10.3 & 27.6 \\
\hline & 61 & 3 & 10.3 & 10.3 & 37.9 \\
\hline & 62 & 6 & 20.7 & 20.7 & 58.6 \\
\hline & 63 & 5 & 17.2 & 17.2 & 75.9 \\
\hline & 64 & 2 & 6.9 & 6.9 & 82.8 \\
\hline & 65 & 3 & 10.3 & 10.3 & 93.1 \\
\hline & 67 & 1 & 3.4 & 3.4 & 96.6 \\
\hline & 68 & 1 & 3.4 & 3.4 & 100.0 \\
\hline & Total & 29 & 100.0 & 100.0 & \\
\hline
\end{tabular}

Table 4 below shows the students score of Post-Test. The Post-Test itself is actually the test for Writing Blended Approach, given to students after receiving some treatments. In this table, it is displayed that the lowest score for the Post-Test was 76-two students having this, and the highest score was 92. The most frequent score coming up is 83 owned by five students. It means that $17.2 \%$ of the students have such score.

Table 4: Post-Test

\begin{tabular}{|c|c|c|c|c|c|}
\hline \multicolumn{7}{|c|}{ Post-Test } \\
\hline \multirow{2}{*}{} & Frequency & Percent & Valid Percent & Cumulative Percent \\
\hline Valid & 76 & 2 & 6.9 & 6.9 & 6.9 \\
\cline { 2 - 6 } & 77 & 1 & 3.4 & 3.4 & 10.3 \\
\cline { 2 - 6 } & 78 & 1 & 3.4 & 3.4 & 13.8 \\
\cline { 2 - 6 } & 80 & 2 & 6.9 & 6.9 & 20.7 \\
\cline { 2 - 6 } & 81 & 2 & 6.9 & 6.9 & 27.6 \\
\cline { 2 - 6 } & 82 & 4 & 13.8 & 13.8 & 41.4 \\
\cline { 2 - 6 } & 83 & 5 & 17.2 & 17.2 & 58.6 \\
\cline { 2 - 6 } & 84 & 4 & 13.8 & 13.8 & 72.4 \\
\cline { 2 - 6 } & 85 & 2 & 6.9 & 6.9 & 79.3 \\
\cline { 2 - 6 } & 86 & 2 & 6.9 & 6.9 & 86.2 \\
\cline { 2 - 6 } & 87 & 1 & 3.4 & 3.4 & 89.7 \\
\cline { 2 - 6 } & 88 & 1 & 3.4 & 3.4 & 93.1 \\
\cline { 2 - 6 } & 90 & 1 & 3.4 & 3.4 & 100.0 \\
\cline { 2 - 6 } & 92 & 1 & 3.4 & 3.4 & \\
\cline { 2 - 6 } & Total & $\mathbf{2 9}$ & $\mathbf{1 0 0 . 0}$ & $\mathbf{1 0 0 . 0}$ & \\
\hline
\end{tabular}

Table 5: Paired Descriptive Statistics

\begin{tabular}{|c|c|c|c|c|c|}
\hline \multicolumn{5}{|c|}{ Paired Samples Statistics } \\
\hline \multicolumn{2}{|c|}{} & Mean & $\mathbf{N}$ & Std. Deviation & Std. Error Mean \\
\hline \multirow{2}{*}{ Pair 1 } & Pre-Test & 61.62 & 29 & 3.406 & .632 \\
\cline { 2 - 6 } & Post-Test & 83.00 & 29 & 3.732 & .693 \\
\hline
\end{tabular}

Table 6: Paired Samples Correlations

Table 6: Paired Samples Correlations
\begin{tabular}{|c|c|c|c|c|}
\hline \multicolumn{5}{|c|}{ Paired Samples Correlations } \\
\hline \multicolumn{2}{|c|}{} & $\mathbf{N}$ & Correlation & Sig. \\
\hline Pair 1 & Pre-Test \& Post-Test & 29 & .840 & .000 \\
\hline
\end{tabular}

In Table 5 Paired Descriptive Statistics above, it is shown that the mean score of the Pre-test was 61.62 and Post-test 83.00. It is also found that the mean of score 
of the students taught by using writing traditional approach called as Pre-Test is 61.62 and the mean of score of the students taught by using Writing Blended Approach called as Post-Test is 83.00. In addition, it is seen that from the standard deviations that the variation in the data (i.e. spread of scores) is a little wider for Post-Test $(\mathrm{SD}=3.732)$ than Pre-Test $(\mathrm{SD}=3.406)$. Here, it is also displayed, in table 7 , that $\mathrm{p}=.000$. Because the Sig. value is less than our alpha of .05 ( $p<.05)$, even $(p<.01)$, we reject the null hypothesis (no difference) for the assumption of homogeneity of variance and conclude that there is a significant difference between the two group's variances. That is, the assumption of homogeneity of variance is not met. Moreover, the t-value (56.364) is greater than the critical value (2.048). In addition, the $95 \%$ confidence interval of the difference does not include zero (0). In short, it means that Writing Blended Approach is more influencing significantly to the students than Writing traditional Approach. This also means that the result indicates that using Writing Blended Approach is more effective than Writing traditional Approach in increasing students' descriptive writing competency.

\begin{tabular}{|c|c|c|c|c|c|c|c|c|c|}
\hline \multicolumn{10}{|c|}{ Paired Samples Test } \\
\hline & & \multicolumn{5}{|c|}{ Paired Differences } & \multirow[t]{3}{*}{$\mathbf{t}$} & \multirow[t]{3}{*}{ df } & \multirow{3}{*}{$\begin{array}{c}\text { Sig. } \\
\text { (2-tailed) }\end{array}$} \\
\hline & & \multirow[t]{2}{*}{ Mean } & \multirow[t]{2}{*}{$\begin{array}{c}\text { Std. } \\
\text { Deviation }\end{array}$} & \multirow[t]{2}{*}{$\begin{array}{l}\text { Std. Error } \\
\text { Mean }\end{array}$} & \multicolumn{2}{|c|}{$\begin{array}{l}95 \% \text { Confidence Interval } \\
\text { of the Difference }\end{array}$} & & & \\
\hline & & & & & Lower & Upper & & & \\
\hline Pair 1 & $\begin{array}{l}\text { Pre-Test - } \\
\text { Post-Test }\end{array}$ & -21.379 & 2.043 & .379 & -22.156 & -20.602 & -56.364 & 28 & .000 \\
\hline
\end{tabular}

To measure the effect size of the using of Writing Blended Approach, " $\boldsymbol{\eta}$ " is computed by using the following formula: (Affana, 2000:42) in Soliman and Ibrahim, 2013.

$$
{ }^{2} \eta=\frac{t^{2}}{t^{2}+d f}
$$

Based on the numeric data from Table 7. Paired Samples Test, the "2 $\boldsymbol{\eta}$ " can be calculated as follows.

${ }^{2} \eta=\frac{t^{2}}{t^{2}+d f}=0.991263379304616$

To get a good interpretation of the result of the Level of Size Effect, table 8 needs to be considered.

Table 8: A Reference to Determine the Level of Size Effect $\left({ }^{2} \eta\right)$

\begin{tabular}{|c|c|c|c|}
\hline \multirow{2}{*}{ Test } & \multicolumn{3}{|c|}{ Effect size criterion } \\
\cline { 2 - 4 } & Small & Medium & Large \\
\hline${ }^{2} \eta$ & 0.01 & 0.06 & 0.14 \\
\hline
\end{tabular}

From the result of the calculation of the effect size, it is shown that the Level of Size Effect $\left({ }^{2} \eta\right)$ is 0.99 . It means the Level of Size Effect $\left({ }^{2} \eta\right)$ which is 0.99 is bigger than 0.14 or $\left({ }^{2} \eta\right)>0.14$. It confirms that the effect size of Writing Blended Approach is large on students' descriptive writing competency. It proves that the effect is significant.

\section{DISCUSSION}

The result of the research shows that Writing Blended Approach can increase students' descriptive writing competency. It can be proved by seeing the Table 5 talking about Paired Descriptive Statistics. The table clearly explores that the mean of score of the students taught by using Writing Blended Approach called Post-Test score mean (83.00) is higher than the mean of score of the students taught by using writing traditional approach called Pre-Test score mean (61.62). Moreover, the standard deviations that the variation in the data (i.e. spread of scores) is a little wider for PostTest (SD=3.732) than Pre-Test (SD=3.406).

The result of the research does not only show that Writing Blended Approach increase students' descriptive writing competency but also shows that there is a significant difference between the two group's variances. It can be proved by analysing the Table 7, Paired Samples Test. The Sig. value is less than our alpha of .05 $(p<.05)$, even $(p<.01)$. We reject the null hypothesis (no difference) for the assumption of homogeneity of variance. It means that the assumption of homogeneity 
of variance is not met. Moreover, the t-value (56.364) is greater than the critical value (2.048). In addition, the 95\% confidence interval of the difference does not include zero (0). Those undeniable facts: the facts that $\mathrm{p}<.05$, the $\mathrm{t}$-value $>$ the critical value and the $95 \%$ confidence interval of the difference does not include zero (0), have proved that Writing Blended Approach is more influencing significantly to the students than Writing traditional Approach.

The findings along with their three undeniable facts lead to effectiveness of the Writing Blended approach in increasing students' descriptive writing competency. It is in line with Hasan \& Akhand (2010) who state that the combination of product and process outperformed the presentation of the learners. There was corroborating evidence to support the view that the blend of both approaches tends to facilitate the learners to undertake a writing task to be developed. The effectiveness can be seen step by step in the following explanation.

The Writing Blended Approach or Blended Approach to Writing in increasing students' descriptive writing competency is effective $\left({ }^{2} \eta=0.99\right)$ because each stage of the Blended approach affected each writing aspect. Firstly, regarding the modelling stage, a model text which was good in terms of genre was provided. This was effective to help the students improve the generic features aspect. Secondly, since the students needed to practice to make sentences using linguistic features used in the text, the practicing stage in the Blended approach existed and was considered effective to help the students improve the textual language and syntactical language aspects. Thirdly, by having the students generate their ideas in group brainstorming, the students were able to enrich their ideas related to a topic given for discussion. And then, the students were able to organize their ideas through planning and mind-mapping. Next, by having done the peer-feedback, the students were able to find the errors in their first draft regarding the textual language, syntactical language, and spelling aspects.
Moreover, the students were also able to apply the self-assessment toward their draft using the peer-assessment guidelines. Afterwards, the students were really helped by the editing stage and writing the second draft stage to improve their first draft based on the peer-feedback. Finally, the students were also helped by the evaluation and teacher's feedback to improve their knowledge on writing since they were evaluated and given feedback toward their final draft by the teacher.

To get more understanding about the findings, it is interesting to see what happen to the traditional/product approach, process approach and blended approach deeply. This can be said as a flashback discussion as the following will show.

Under the traditional approach (in writing usually product approach), reflected by the pre-test, it was found that the maximum number of students tried to recall their previous knowledge and some of them imitated model writing and some reproduced the original. The students were not helped by this approach in producing a good composition given in the exam hall since they failed to showcase their ability to write effectively the structure of the composition in their answer scripts.

Under the process approach given in the middle of the treatment period called as a very mini test considered as a learning process, it was observed that most of the students faced problems in brainstorming and organizing their ideas cohesively as they were not familiar with the method. The observation showed that later they could cope with it, but it took a long time to gather their ideas and organize them. It was noticed that some failed even after their several attempts as they could not extract the important points necessary for the topic. It was also found that the students retreated back to their old fashioned paragraph writing without providing the structure of a paragraph, namely topic sentence, supporting details and a conclusion. It took substantial time to correct them. Moreover, it was found that some students highly 
failed to remember to write topic sentence of a paragraph, even giving two or three paragraphs when being asked to write a paragraph only.

As the product approach and process approach were not quite so satisfying in that experiments, it is interesting to make them balanced by collaborating those writing approaches. As there is a tendency to overemphasis of grammar and final product in the Junior High School in Indonesia although, personally speaking, it is not an obligation to do that, students are supplied with the texts playing a key role in their learning. In the traditional approach, the students are restricted within a supply of texts and can only produce or reproduce what they have as inputs from the sample texts. In fact, the evaluation of a writing is done on the usage of correct grammar, a range of vocabularies (specified in some cases), meaningful punctuation, accurate spelling (Hedge, 1988). Besides, for the concentration on the final product, students fail to realize that writing is a recursive process rather than a linear one. So, when in the tertiary level, like in an English course, they deal with a completely different context writing having a wide range of genre and topics requiring sufficient amount of critical thinking. The study showed that the students were reluctant to learn the different approaches the researcher wanted to implement in the classes as they were more concerned about examinations and result; as a result, the students utterly failed to live up to the performance of what was expected.

Following (Batstone, 1994), to improve the situation it is needed to mix 'the careful control of language for learner (as in product), and the creative use of language by the learner (as in process)' (Kim and Kim, 2005, pp.7-8). Product and process approaches have been incorporated in a classroom called blended writing approach in the following ways:

Guided Brainstorming has been adopted where major ideas/points have been supplied and the students were asked to organize sub-points to support them in the brainstorming session on 'The Elephant'.

Top down approach in the organization of ideas has also been adopted in which a text has been given and the students were asked to extract the important ideas/points on which it is written.

Finally, the students were asked to develop the extracted important ideas/points in to a good essay made with their own words.

Under the blended approach given in the end of the treatment period in which the test was called as Post-test, it was observed that most of the students got more confident than that in traditional approach reflected by the pre-test. The students were helped by this approach in producing a good composition proven by their capability to write the structure of the composition effectively in their answer sheet.

From the explanation above, it is clear that writing blended approach can increase the students' descriptive writing competency.

\section{CONCLUSION}

Based on the findings, the blended approach to teaching writing is an effective approach to increase the students' descriptive writing competency. It is in line with Kim and Kim (2005, p. 7-8) that "we needed to mixed the careful control of language for learner (as in product), and the creative use of language by the learner (as in process) to improve the situation". In addition, "both process and product approaches are significant in teaching writing in EFL/ESL context" (Hasan and Ahkand, 2010, p. 84). In product-based approach, it is important for a student to engage in imitating, copying, and transforming models of the correct language (Nunan, 2000). Likewise, the process-based approach is beneficial to help the students generate their ideas and organize them in a systematic way, which helps the students to write fluently. Along these lines, blended approach: the combination of the product and process approaches to teaching 
descriptive writing, is beneficial for teachers to increase students' descriptive writing competency.

Considering the findings, theoretically, this study enriches the literature on teaching writing in Indonesian EFL context since there is no study existing in Indonesian about the use of the product and process-based approach combination to teaching writing at Junior High School level. Practically, the blended approach to writing may be implemented by the English teachers in their classroom because of its benefit to increase students' descriptive writing competency.

Therefore, it is suggested that the ESL/ EFL teachers would like to use the blended approach to writing in writing class particularly to increase students' descriptive writing competency. In the product and process approaches lay benefits and drawbacks; as a consequence, it is convinced that complementary use of both approaches helps student writers develop their descriptive writing competency in using language by experiencing a whole writing process as well as gain knowledge from the model texts. Such a complementary use of both approaches would help students to be Authors rather than Copiers, and so have the potential benefit of integrating critical thinking into their academic writing.

\section{Acknowledgement: None}

\section{Conflict of Interest: None}

\section{Source of Funding: None}

\section{REFERENCES}

1. Affana, a. (2000). The effect size in educational research. Palestinian Educational Studies Journal 3(6).

2. Awad Soliman Keshta, Ismail Ibrahim Harb. The Effectiveness of a Blended Learning Program on Developing Palestinian Tenth Graders' English Writing Skills. Education Journal. Vol. 2, No. 6, 2013, pp. 208-221. doi: $10.11648 /$ j.edu.20130206.12
3. Batstone, R. (1994). Product and process: Grammar in the second language classroom. In Bygate, Martin, A. Tonkyn \& E. Williams (Eds.), Grammar and the language teacher. (pp.224-36). New York: Prentice Hall.

4. Flower, L., \& Hayes, J. R. (1981). A cognitive process theory of writing. College Composition and Communication, 32, 365387.

5. Gardner, A., \& Johnson, D. (1997). Teaching personal experience narrative in the elementary and beyond. Flagstaff, AZ: Northern Arizona Writing Project Press.

6. Hasan \& Akhand (2010). Approaches to Writing in EFL/ESL Context: Balancing Product and Process in Writing Class at Tertiary Level. Journal of NELTA Vol. 15 No. 1-2 December 2010

7. Hayes, J.R. and L.S. Flower, 1980. Identifying the organization of writing processes. In L. W. Gregg and E.R. Steinberg (Eds.), Cognitive processes in writing. Hillsdale, NJ: Erlbaum.

8. Hedge, T. (1988). Writing. Oxford: Oxford University Press.

9. Kim, Y. \& Kim, J. (2005). Teaching Korean university writing class: balancing the process and the genre approach. Asian EFL Journal Online, 7 (2),69- 90. Retrieved on 25th Jan. 2010 from http://www.asian-efljournal.com/June_05_yk\&jk.php

10. Nunan, D. (1991). Language teaching methodology: A textbook for teachers. England: Longman.

11. Nunan, D. (1999). Second language teaching \& learning. Boston: Heinle Cengage Learning.

12. Richards, J., Platt, J. \& Weber, H. (1985). Longman dictionary of applied linguistics. London: Longman.

13. Richards, T., Berninger, V. W., Winn, W., Swanson, H. L., Stock, P., Liang, O.,\& Abbott, R. (2009). Differences in fMRI activation between children with and without spelling disability on 2-back/0-back working memory contrast. Journal of Writing Research, 1(2), 93-123.

How to cite this article: Hidayat J. Developing writing blended approach to increase students' descriptive writing competency. International Journal of Research and Review. 2021; 8(12): 130-138. DOI: https://doi.org/10.52403/ijrr. 20211218 